responsibility given to the prisoners. The third aim of sentencing, the protection of the public, is a matter of weighing values and not a matter for scientific research. The question here is: What offences are considered so serious that society must be protected against them for long periods ? It is suggested that in the case of the persistent petty thief, society must be prepared to take risks. In the case of certain sex offenders and professional criminals society has the right to protect itself.

The final issues discussed are: the indeterminate sentence and the question of a sentencing tribunal. Argu- ments are brought against both of these. The indeterminate sentence is disturbing to prisoners who are not granted parole. If there is a sentencing tribunal then appeals against sentence will go before the courts and we are back where we started, and if sentencing is to have a general deterrent effect, then sentencing must be done as soon as possible after the trial. A.t the same time, it is suggested that special sentences such as corrective training and preventive detention should be abolished and the allocation of offenders sentenced to custodial care should be left to the prison authorities.

\title{
PRESIDENT FOR 1964 OF THE BRITISH ASSOCIATION
}

\section{LORD BRAIN}

$\mathrm{T}$ HE RIGHT HON. LORD BRAIN, the well-known neurologist, has been elected president for 1964 of the British Association for the Advancement of Science. Lord Brain will deliver his presidential address at the next annual meeting (1964) in Southampton. The British A.ssociation has made what will prove to be an excellent choice, because not only is Lord Brain perhaps the first clinician to be awarded this important honour since Lord Lister, but also, like Lister, he is a medical man who has done much to set medicine on a scientific footing.

Lord Brain was born in 1895 and received his pre. liminary education at Mill Hill School and New College, Oxford.

A.t Oxford he was taught zoology by Sir Julian Huxley and for a time had J. B. S. Haldane as a tutor. He also came under the influence of Sherrington and Bazett. Proceeding to the London Hospital for his clinical work, he had as a teacher George Riddoch, fresh from his collaboration with Henry Head on the effects of war injuries on the spinal cord. Riddoch started him on his career in neurology by introducing him to Maida Vale Hospital, to the staff of which he was later appointed, and soon after that he became neurologist to the London Hospital.

There has always been a close link between neurology and ophthalmology, so Brain later joined the staff of the Royal London Ophthalmic Hospital (Moorfields), which led to his interest in the ocular symptoms of thyroid disorders, particularly exophthalmos, and his description of the syndrome exophthalmic ophthalmoplegia helped to elarify the endocrine factors responsible for exophthalmos.

Shortly after the War, his attention was directed to disorders of the joints of the neck as a cause of neurological symptoms, and this helped to open up a new field of clinical neurology dealing with spinal cord syndromes, and more recently with the effects of disease of the cervical intervertebral disks on the circulation through the brain. About this time, in collaboration with others, Lord Brain was one of the first to describe degenerative changes in the nervous system associated with cancer, and this has led to the recognition of a wide range of disorders complicating cancer, but not directly due to the spread of the growth, and he is now directing a team carrying out research in this field, with the support of the British Empire Cancer Campaign.

An early interest in psychology and psychiatry, stimulated by developments in psychological medicine during the First World War, led Brain to investigate the correlations between brain and mind illustrated by the effects of brain damage, and during the Second World War he wrote on some visual perceptual disorders and on the significance of handedness in relation to cerebral function, and recently he has performed work on disorders of language, thereby continuing the London Hospital neurological tradition springing from Hughlings Jackson and Henry Head. The physiology and pathology of perception and consciousness and their philosophical implications remain a continuing interest.

Lord Brain married Stella, daughter of the late Dr. Reginald Langdon-Down, whose father, Dr. John Langdon-Down, described mongolism, which has recently attracted much interest on account of the discovery of its basis in a chromosomal abnormality. Lady Brain has many medical relatives, and a cousin of hers is the wife of Prof. A. V. Hill, a former president of the British Association.

Lord Brain has many honours to his credit; a most intriguing point is that (1) his name is Brain (2) he is a world-authority on the brain; (3) he is the editor of the excellent specialist journal Brain.

\section{THE ABERDEEN REGION}

\section{The North-East of Scotland}

A Survey prepared for the Aberdeen Meeting of the British Association for the Advancement of Science, 1963. Pp. viii + 256. (Aberdeen: The Central Press for the Local Committee, 1963.) n.p.

A LTHOUGH it is not usual to start reviewing a book from its end, in the case of this book, The NorthEast of Scotland, it seems the most obvious place. Between the last page and the cover is provided the best introduction to any area - a detailed map. The present one, a $1 / 5$ in. to the mile coloured map, was specially prepared by Messrs. John Bartholomew and Son, Ltd., Edinburgh, for the occasion of the visit of the British Association for the Advancement of Science to Aberdeenas was the Survey itself.
Twenty-four contributors, mainly from the University of Aberdeen, have produced a Survey full of information for the members of the Association. It consists of twenty. six essay reviews dealing with various aspects of the area, which for the most vary from two to twenty pages. It opens with a succinct account of North-East Scotland which, like a clenched knuckle, projects from the Grampians to the North Sea. Essentially it is concerned with the counties of Aberdeenshire, Banffshire and Kincardineshire, but in part Moray and Nairnshire are included.

Having thus defined the theatre for the British Association 1963 meeting, the platform is next laid out by essays on the geology and structure (13 pp.), geomorphology (17 pp.), climate (5 pp.), soils ( 8 pp.), flora ( 8 pp.), and fauna (13 pp.). North of the Highland Boundary Fault 